\title{
云南大围山种子植物区系海拔梯度格局分析
}

\author{
王 娟 ${ }^{1}$ 马钦彦 ${ }^{2}$ 杜 凡1 杨宇明 ${ }^{1}$ \\ （1 西南林学院, 昆明 650224）（2 北京林业大学, 北京 100083）
}

\begin{abstract}
摘 要 海拔梯度包含了多种环境因子的梯度效应, 因而研究山地植物区系的海拔梯度格局对揭示植物区系的环 境梯度变化规律、了解生物适应性和生物多样性沿海拔梯度的变化趋势等具有重要意义。为了探讨山地植物区系 构成特征及其海拔梯度的生态意义, 该文根据对大围山国家级自然保护区植被线路调查和垂直样带调查, 并结合 文献研究等获得的植物区系资料,分析了该保护区种子植物区系构成的基本特征及其随海拔梯度的变化趋势; 利 用系统聚类的方法寻找和研究大围山植物区系沿海拔梯度变化的断点位置。研究结果表明: 1)大围山大多数热带 成分分布的上限位于海拔 $1500 \mathrm{~m}$ 左右, 以此为界划分热带雨林和常绿阔叶林是合理的。2)湿润雨林分布于海拔 $700 \mathrm{~m}$ 以下; 山地雨林分布于海拔 700 1 $500 \mathrm{~m}$; 季风常绿阔叶林分布于海拔 $1300 \sim 1800 \mathrm{~m}$; 山地苔蘚常绿阔叶林 分布于海拔 $1800 \mathrm{~m}$ 以上; 在海拔 $2100 \mathrm{~m}$ 以上的迎风坡面、土层㾑薄的地段分布有不甚典型的山地苔䰻矮林。

关键词 大围山 地理成分 海拔梯度 聚类分析
\end{abstract}

\section{ALTITUDINAL PATTERNS OF SEED PLANTS ON DAWEI MOUNTAIN, YUNNAN PROVINCE, CHINA}

\author{
WANG Juan ${ }^{1}$ MA Qin-Yan ${ }^{2}$ DU Fan ${ }^{1}$ and YANG Yu-Ming ${ }^{1}$ \\ (1 Southwest Forestry College, Kunming 650224, China) \\ (2 School of Resources and Environment, Beijing Forestry University, Beijing 100083, China)
}

\begin{abstract}
Altitudinal gradients incorporate multiple resource gradients which vary continuously in different fashions. Studies of mountain floristic patterns along altitudinal gradients has revealed regular patterns of the flora along environmental gradients, changing trends in biodiversity along altitudinal gradients as well as a better understanding of biological fitness. To explore the floristic compositional characteristics and the ecological significance of floristic patterns along altitudinal gradients in the China National Natural Reserve of Dawei Mountain in southeast Yunnan, the flora was quantified along two transects, one on the southwest slope and the other on the northeast slope of the reserve, including a vertical vegetation transect. Further investigations were conducted on the flora of Dawei Mountain which have ever been accounted for in the literature, such as Flora of Yunnan, The Seed Plant in Yunnan and so on. The structural characteristics of the flora and the altitudinal distribution patterns of its floristic components were analyzed. Systematic cluster analysis was applied to the data to determine how composition changed with changes in altitude and climate. The conclusions can be summarized as follows: 1) There was a strong boundary that differentiated tropical floristic elements from evergreen broad-leaved forests at an altitude of approximately $1500 \mathrm{~m}$; 2) Cluster analysis showed that humid rain forests occurred below $700 \mathrm{~m}$ a.s.l, mountain rain forests were between $700 \mathrm{~m}$ and $1500 \mathrm{~m}$, monsoon evergreen broad-leaved forests were between $1300 \mathrm{~m}$ and $1800 \mathrm{~m}$, and the mountain mossy evergreen broad-leaved forest occurred above $1800 \mathrm{~m}$ a.s.l. Non-representative mountain mossy dwarf forests (above $2100 \mathrm{~m}$ ) in the area are distributed on windward slopes and barren land on the mountain slopes.
\end{abstract}

Key words Dawei Mountain, Altitudinal gradient, Clustering analysis

植物分布区理论认为物种分布区是物种形成过 程的空间反映 (OCHOBbI, 1965)。山地不仅反映和 浓缩了水平地带性的自然地理特点和生物地理特
征,成为验证和发展有关生物多样性理论的理想场 所(方精云等, 2004), 也由于高度异质化的生境和相 对较低的人类干扰强度, 在地质历史上常成为大量 
物种的避难所和新兴植物区系分化的摇篮, 是全球 生物多样性研究重点区域 (Messerli \& Ives，1997; Myers et al.，2000；Körner，2000）。生物多样性格局 形成机制的研究主要是从不同时空尺度上综合研究 森林植物、森林群落类型和森林景观格局与古代或 现代生态环境的关系, 分析森林生物多样性的历史 及其与生态条件的关系 (Rosenzweig, 1992，1995; Rohde, 1992)。大围山国家级自然保护区地处热带北 缘, 因其特殊的地理位置, 地形地势, 悠久的地质历 史, 高度异质性生境, 孕育了丰富的植物资源, 有野 生种子植物 188 科 994 属 3027 种及变种, 其物种密 度高达 19.69 种 $\bullet \mathrm{km}^{-2}$, 成为云南省植物种类最丰富 的地区之一。此外, 区内还发育有云南省其它地区 罕见的茂密高大湿润雨林一一国大陆湿热性最强 的雨林类型 (吴征殓, 1980; 吴征镒和朱彦丞, 1987), 相对高差达 $2140 \mathrm{~m}$, 使其保存有较为完整的植被垂 直带谱, 成为研究有关植被与环境关系的重要场所。 植物区系分析研究对深入了解生物的适应性、分布 规律和生物多样性变化等均有重要意义。鉴于此, 本文依据大围山分布的种子植物实地调查资料和文 献资料就植物区系成分构成的基本特征及其随海拔 梯度的分布格局进行探讨分析。

\section{1 研究地概况}

大围山国家级自然保护区位于北回归线以南, $103^{\circ} 20^{\prime} \sim 104^{\circ} 03^{\prime} \mathrm{E}, 22^{\circ} 35^{\prime} \sim 23^{\circ} 07^{\prime} \mathrm{N}$, 面积 153.7 $\mathrm{km}^{2}$ 。保护区所处山地位于滇中湖盆地高原南侧, 又 处在滇东南喀斯特高原的西缘, 它隔红河与哀牢山 相望, 是南溪河、新现河与红河等大河共同切割而成 的构造侵蚀中山山地, 在保护区西南与东北两侧分 别有红河和南溪河通过。区内最高峰大尖山海拔 $2365 \mathrm{~m}$, 次高峰大围山, 海拔 $2354 \mathrm{~m}$, 最低处海拔 $225 \mathrm{~m}$ 。因其四周有高山阻挡, 仅东南面靠狭窄的红 河谷口(海拔 $76.4 \mathrm{~m}$ ) 通向越南北部湾, 成为全省受 东南暖湿气流影响最深的地区。使该区雨热丰富, 夏天高温多雨, 冬季暖湿多雾, 年均温 $22.6{ }^{\circ} \mathrm{C}$, 最冷 月(一月)均温 $15.2{ }^{\circ} \mathrm{C}$, 最热月 (七月)均温 $27.7{ }^{\circ} \mathrm{C}$, 年最低温多年平均值为 $5.8{ }^{\circ} \mathrm{C}$, 大于 $10{ }^{\circ} \mathrm{C}$ 的年积温 $8246.2{ }^{\circ} \mathrm{C}$, 全年无霜。深处谷地内部的河口, 平均 年降水量达 $1777.7 \mathrm{~mm}$, 随山体海拔增高, 气温下降 和地形雨出现,最多降水量高达 $2649.5 \mathrm{~mm}$ 。山体 上随海拔升高依次分布着砖红壤、赤红壤、红壤、黄 壤、黄棕壤 5 个土类, 其中以黄壤分布最广, 占整个 保护区的 $85 \%$ 左右。同时, 从低海拔到高海拔依次
分布有湿润雨林、山地雨林、湿性季风常绿阔叶林、 山地苔藓常绿阔叶林和山顶苔藓矮林等植被类型。

大围山自然保护区位于滇东南云南高原向南倾 斜面南缘的一列断块山地上, 处于大陆东南亚热带 北缘热带生物区系向云南高原亚热带生物区系过渡 的地带, 同时又处于 “田中线” (李锡文和李捷, 1992) 南端附近东亚区系两大成份相汇处。该区在植被地 理、植物区系地理和生物多样性保护研究上具有较 高的科学价值和实践意义。19 世纪以来, 中外学者 到该区进行植物标本采集和考察, 其成果主要集中 反映在《云南植物志》、《云南种子名录》等专著中。 1997 年以来西南林学院组织专家对大围山国家级 自然保护区进行了全面的综合考察。

\section{2 研究内容与方法}

\section{1 大围山种子植物及其分布的海拔范围}

对大围山自然保护区山地植被进行研究, 是从 大围山保护区西南坡面和东北坡面两个坡面进行。 分布于低海拔的湿润雨林, 因历史上的不断农垦和 采伐, 其原始森林植被在本保护区内多已遭到破坏, 目前仅在一些陡峻幽深的峡谷中还保留有一些残林 片段。因此, 调查包括 1) 从海拔 $300 \mathrm{~m}$ 处开始到海 拔 $2356 \mathrm{~m}$ 的大尖山顶峰, 进行线路调查, 并采集植 物标本, 从而获取 $300 \sim 2356 \mathrm{~m}$ 之间出现的植物种 类;2)从海拔 $800 \mathrm{~m}$ 处开始到海拔 $2356 \mathrm{~m}$ 的大尖山 顶峰, 以海拔 $50 \mathrm{~m}$ 为间隔, 因地形破碎和群落结构 变化取 $400 \sim 1000 \mathrm{~m}^{2}$ 不等的样方调查, 从而获取 $800 \sim 2356 \mathrm{~m}$ 之间出现的植物种类; 3 ) 根据《云南植 物志》、《中国植物志》、《滇东南红河地区种子植物》 (税玉民, 2003) 等文献记载, 对大围山 $300 \mathrm{~m}$ 以上地 区所采集的标本加以补充。据此确定大围山种子植 物及其分布的海拔范围, 并建立大围山种子植物区 系数据库,包括科、属分布区类型 (吴征镒, 1991)、海 拔、生境、生活型及其叶形态特征等。

因大围山地形破碎, 导致环境空间异质性强烈, 植物种类的数量与调查面积和包含的生境性有直接 关系。所以将大围山保护区不同坡面相同海拔高度 段的样方结合起来分析。

\section{2 种子植物地理成分的垂直梯度分析}

以 $100 \mathrm{~m}$ 为高差划分海拔区间, 统计每一个区 间内种子植物世界分布属占全部属的百分比 $(T 1)$ 、 其它 14 个分布区类型的属数占非世界分布属数的 百分比( $T 2 \sim T 15)$, 即泛热带分布 $(T 2)$ 、热带亚洲和 热带美洲间断分布 $(T 3$ )、旧世界热带分布 $(T 4)$ 、热 
带亚洲至热带大洋洲分布 $(T 5$ )、热带亚洲和热带非 洲分布 $(T 6$ )、热带亚洲分布 $(T 7)$ 、北温带分布 $(T 8)$ 、 东亚和北美洲间断分布 ( T9)、旧世界温带分布 $(T 10)$ 、温带亚洲分布 $(T 11)$ 、地中海区、西亚至中亚 分布 $(T 12)$ 、中亚分布 $(T 13)$ 、东亚分布 $(T 14)$ 和中国 特有分布 $(T 15)$, 以及越南至华南分布 $(T 7.4)$ 、缅 甸、泰国至华西南分布 $(T 7.3$ )、中国 - 喜马拉雅分布 ( T14.1) 和中国-日本分布属数各占非世界分布属 数百分比 (T14.2), 温带成分属与热带成分属数之 比 $\left(T_{\mathrm{w}} / T_{\mathrm{r}}\right)$ 。

\section{3 种子植物区系成分的聚类分析}

在垂直梯度分析的基础上，探讨和识别大围山 种子植物地理成分沿海拔梯度变化的断点, 为大围 山垂直植被带划分提供依据。在各海拔区间分别以 994 个种子植物属在各海拔段属的分布区类型构成 的百分比和各个分布区类型下属所含种数的百分比 进行系统聚类分析(阳含熙和卢泽愚, 1981)。

用距离系数度量各海拔段区系构成的变化特 征, 依据平均距离法进行聚类（阳含熙和卢泽愚, 1981; 唐守正, 1986; 徐克学, 1994）。

平均距离法: 用最短距离与最长距离的均值定 义类的距离。类 $G_{p}$ 与类 $G_{q}$ 合并成新类 $G_{r}$, 则 $G_{r}$ 与 $G_{i}$ 任一类的距离递推公式为 (式中, $D_{i p} 、 D_{i q} 、 D_{p q}$ 分 别为 $G_{i} 、 G_{p} 、 G_{q}$ 之间的距离):

$D_{i r}=\sqrt{\frac{1}{2} D_{i p}^{2}+\frac{1}{2} D_{i q}^{2}+\frac{1}{4} D_{p q}^{2}}$

距离公式如下: $\cdots, n)$

欧氏距离 $d_{i j}=\sqrt{\sum_{t=1}^{p}\left(X_{i t}-X_{j t}\right)^{2}} \quad(i, j=1,2$,

\section{3 结果与分析}

\section{1 种子植物区系成分海拔梯度格局}

植物区系地理成分不仅反映该区系与全球各地 植物区系的历史渊源和相互关系，也是对当地环境 条件(气候)的一种表征(沈泽吴等,2001)。以下分 析大围山种子植物地理成分与海拔垂直梯度相关性 (图 1)。

\section{1 .1 热带成分分布格局}

热带成分诸类 $(T 2 \sim T 7)$ 均随海拔上升而减 小, 反映了与其属性相吻合的趋势, 但其随海拔上升 而减小的速率存在明显差异。海拔 $300 \mathrm{~m}$ 至 $1300 \mathrm{~m}$ 之间, 热带亚洲成分 $(T 7$ ) 稳定在 $32 \%$, 海拔 $1300 \mathrm{~m}$
以上则出现急速的下降趋势, 反映出在大围山海拔 $1300 \mathrm{~m}$ 是大多数热带亚洲成分分布极限高度。在 海拔 300 1500 m 之间, 热带亚洲至热带大洋洲成 分 $(T 5)$ 和热带亚洲至热带非洲成分 $(T 6)$ 则所占比 例变化不大, 而海拔 $1500 \mathrm{~m}$ 以上几呈直线递减。 在海拔 $300 \mathrm{~m}$ 至 $2300 \mathrm{~m}$ 之间, 泛热带成分 $(T 2)$ 、热 带亚洲和热带美洲间断成分 (T3) 和旧世界热带成 分 $(T 4)$ 在整个山体上均随海拔梯度呈平缓的下降 趋势, 无明显断点, 但各个成分所占比例又有明显差 异。泛热带成分随海拔的升高从 $25.5 \%$ 下降至 $21.0 \%$ ，旧世界热带成分则从 $13.0 \%$ 降至 $7.0 \%$ 、热 带亚洲和热带美洲间断成分则从 $4.2 \%$ 降至 $2.1 \%$ 。 依据热带成分在海拔梯度上的分布推断, 大多数热 带成分在大围山分布的极限高度为海拔 $1500 \mathrm{~m}$ 。

此外，热带亚洲成分中的越南至华南分布 ( T7.4) 与缅甸、泰国至华西南分布 $(T 7.3)$ 两个亚 型随海拔梯度的变化趋势基本一致,但越南至华南 分布所占比例始终占优势地位,约为缅甸、泰国至华 西南分布属数的四倍, 表明大围山植物区系与越南、 华南地区植物区系的紧密联系。

\section{1 .2 温带成分分布格局}

温带成分诸类 $(T 8 \sim T 14)$ 所占比例均随海拔梯 度而上升, 显示了与其属性相吻合的趋势。温带成 分中数量最多的东亚成分 $(T 14)$ 、北温带成分 $(T 8)$ 和旧世界温带成分 $(T 10)$, 其所占比例均随海拔梯 度明显上升。温带亚洲成分 $(T 11)$ 和东亚北美间断 成分 $(T 9)$ 所占比例则随海拔增加而缓慢增长。与 干旱生境有深远联系的地中海、西亚至中亚分布 $(T 12)$ 和中亚分布 $(T 13)$ 所占比例较小或不存在, 则 反映历史上大围山生境的湿润状况。

大围山处于东亚区系两大成分的相汇处, 是东 西成分的结合点 (李锡文和李捷, 1992)。因此东亚 组诸类是该地植物区系中富有特色的成分。东亚分 布 (T14) 随海拔升高保持了强劲的上升趋势, 并在 海拔 $1900 \sim 2100 \mathrm{~m}$ 段达到峰值。但它的两个分布 亚型中国-喜马拉雅分布 $(T 14.1)$ 与中国-日本分布 ( T14.2)沿海拔梯度表现了不同的格局, 中国-日本 分布随海拔梯度格局的变化不大, 而中国-喜马拉雅 分布则随海拔升高表现出强烈的上升趋势。这可能 与第三纪末喜马拉雅运动期间中国西南山地发生不 同程度的抬升 (周庭儒和任森厚, 1984), 为中国-喜 马拉雅植物区系成分可沿中高山山地环境向东南扩 散创造了条件有关。 

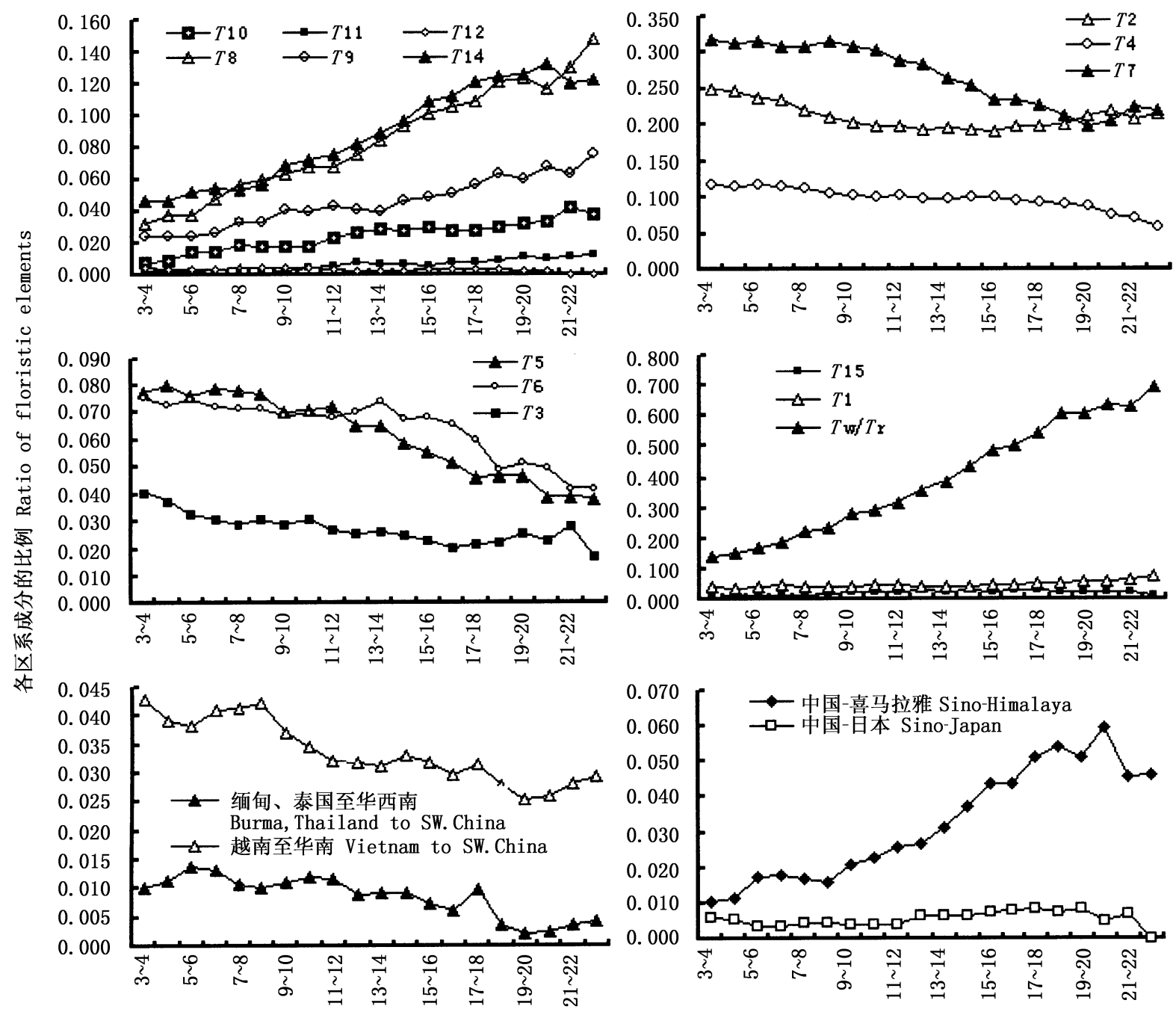

海拔 Elevation (100 m)

海拔 Elevation (100 m)

图 1 大围山种子植物区系中各地理成分的垂直梯度分布

Fig.1 Vertical distribution of the geographical elements of the flora of Dawei Mountain

$T 1$. 世界分布 Cosmopolitan T2. 泛热带分布 Pantropic $T 3$. 热带亚洲和热带美洲间断分布 Tropical Asia \& Tropical American disjuncted T4. 旧 世界热带分布 Old World TropicsＴ5. 热带亚洲至热带大洋洲分布 Tropical Asia \& Tropical Australasia T6. 热带亚洲至热带非洲分布 Tropical Asia to Tropical Africa T7. 热带亚洲分布 Tropical Asia T8. 北温带分布 North Temperate T9. 东亚和北美间断分布 E. Asia \& N. American disjuncted $T 10$. 旧世界温带分布 Old World Temperate T11. 温带亚洲分布 Temperate Asia T12. 地中海、西亚至中亚分布 Mediterranea, W. Asia to C. Asia T14. 东亚分布 E. Asia T15. 中国特有分布 Endemic to China $T_{\mathrm{W}} / T_{\mathrm{r}}$ : 温带属数与热带、亚热带属数之比 Ratio of the number of temperate genera to the number of tropical and subtropical genera

\section{1 .3 中国特有成分分布格局}

中国特有属 $(T 15)$ 的比例随海拔升高而呈现微 弱的上升趋势, 表现了其与温带成分的联系。在海 拔 $1100 \sim 1300$ m 段达到峰值并保持到 1700 $1900 \mathrm{~m}$ 段, 此后呈现下行格局, 当然, 在低海拔段所 占比例较低可能与原生植被受人为干扰影响较大有 关。

3.1 .4 温带成分与热带成分之比分布格局

不同海拔段内种子植物属的温带成分与热带成
分比值 $\left(T_{\mathrm{W}} / T_{\mathrm{r}}\right.$ ) 沿海拔梯度稳定上升 (图 1), 但即 使到近山顶处其值也小于 1 , 此外, 按不同海拔高度 样地资料统计森林群落中种子植物属的分布区类 型, 其温带成分与热带成分属数的比值(表 1) 在本 区海拔 $300 \sim 2350 \mathrm{~m}$ (山顶) 内其值也都小于 1。这 充分反映了大围山植物区系的热带性质, 说明大围 山上不存在区系平衡点。图 1 所示的各条曲线在总 体趋势之外表现出不同程度波动起伏与不同地形部 位水热条件差异明显有关。 
表 1 不同海拔段群落及其区系 $\boldsymbol{T r} / \boldsymbol{T} \mathbf{w}$ 值的比较

Table 1 Comparison of several forest communities at different elevations and their $T_{\mathrm{W}} / T_{\mathrm{r}}$ ratio

\begin{tabular}{|c|c|c|c|c|c|c|c|}
\hline $\begin{array}{c}\text { 群落类型 } \\
\text { Community type }\end{array}$ & $T_{\mathrm{W}} / T_{\mathrm{r}}$ & $\begin{array}{c}\text { 海拔 } \\
\text { Elevation }(\mathrm{m})\end{array}$ & $\begin{array}{l}\text { 坡向 } \\
\text { Aspect }\end{array}$ & $\begin{array}{l}\text { 坡度 } \\
\text { Slope }\end{array}$ & $\begin{array}{l}\text { 土壤类型 } \\
\text { Soil types }\end{array}$ & $\begin{array}{c}\text { 人为干扰 } \\
\text { Human distur bance }\end{array}$ & $\begin{array}{c}\text { 地点 } \\
\text { Site }\end{array}$ \\
\hline $\begin{array}{l}\text { 云南龙脑香 Dipterocarpus tonkinensis、隐翼 } \\
\text { Crypteronia paniculata、线毛番龙眼 Pometia } \\
\text { Tomentosa }\end{array}$ & 0.12 & 820 & $\mathrm{E}$ & $30^{\circ}$ & $\begin{array}{l}\text { 黄色砖红 壤 } \\
\text { Yellow latosol }\end{array}$ & $\begin{array}{l}\text { 较多 Time } \\
\text { and again }\end{array}$ & $\begin{array}{l}\text { 糯咪 村 Nuomi } \\
\text { Cun }\end{array}$ \\
\hline $\begin{array}{l}\text { 高阿丁枫 Altingia excelsa、马蹄荷 Exbucklan- } \\
\text { dia populnea }\end{array}$ & 0.12 & 1000 & $\mathrm{EN}$ & $18^{\circ}$ & & $\begin{array}{l}\text { 频繁 } \\
\text { Frequent }\end{array}$ & \\
\hline $\begin{array}{l}\text { 红花荷 Rhodoleia parvipetala、兰果树 } N y s s a \\
\text { sinensis、山韶子 Nephium chryseum、滇木花生 } \\
\text { Madchuca pasquieri }\end{array}$ & 0.13 & 1070 & SW & $20^{\circ}$ & $\begin{array}{l}\text { 黄色赤红壤 } \\
\text { Yellow latosolic } \\
\text { red soil }\end{array}$ & $\begin{array}{l}\text { 几乎无 Al- } \\
\text { most no }\end{array}$ & $\begin{array}{l}\text { 围山老寨 Weis- } \\
\text { han Laozhai }\end{array}$ \\
\hline $\begin{array}{l}\text { 锈毛梭子果 Eberhardtia aurata、贫花厚壳桂 } \\
\text { Lithocarpus megahylla、草鞋 木 Macaranga } \\
\text { henryi、大叶石栋 Cryptocarya depauperata }\end{array}$ & 0.15 & 1360 & $\mathrm{E}$ & $15^{\circ}$ & $\begin{array}{l}\text { 黄色赤红 壤 } \\
\text { Yellow latosolic } \\
\text { red soil }\end{array}$ & 极少 Few & $\begin{array}{l}\text { 子 母 河 沟 等 } \\
\text { Zimuhe Gouqing }\end{array}$ \\
\hline $\begin{array}{l}\text { 红花荷 Rhodoleia paripetala、大叶石栋 Litho- } \\
\text { carpus megalophyllus、丛花厚壳桂 Cryptocarya } \\
\text { densiflora }\end{array}$ & 0.20 & 1650 & $\mathrm{EN}$ & $25^{\circ}$ & 黄壤 Yellow soil & 较少 Less & $\begin{array}{l}\text { 田 头 山 顶 } \\
\text { Tiantou Mountain } \\
\text { Topot }\end{array}$ \\
\hline $\begin{array}{l}\text { 东南石栋 Lithocarpus harlandii、毛木荷 Schi- } \\
\text { ma villosa、梭子果 Eberhardtia tonkinensis }\end{array}$ & 0.18 & 1660 & $\mathrm{~N}$ & $30^{\circ}$ & $\begin{array}{l}\text { 山地黄壤 Moun- } \\
\text { tain yellow soil }\end{array}$ & 较少 Less & $\begin{array}{l}\text { 大围山 Dawei } \\
\text { Mountain }\end{array}$ \\
\hline $\begin{array}{l}\text { 华南石栋 Lithocarpus harlandii、团香果 Lin- } \\
\text { dera latifolia、壳菜果林 Mylitara laosensis }\end{array}$ & 0.32 & 1705 & $\mathrm{SE}$ & $15^{\circ}$ & $\begin{array}{l}\text { 山地黄壤 Moun- } \\
\text { tain yellow soil }\end{array}$ & $\begin{array}{l}\text { 较多 Time } \\
\text { and again }\end{array}$ & $\begin{array}{l}\text { 六公里 Six kilo- } \\
\text { metre }\end{array}$ \\
\hline $\begin{array}{l}\text { 硬斗石栎 Lithocarpus hancei、木瓜红 Re- } \\
\text { hderodendron macrocarpus, 长圆臀果木 } \\
\text { Pygeum oblongum }\end{array}$ & 0.24 & 1870 & $\mathrm{WN}$ & $20^{\circ}$ & 黄壤 Yellow soil & $\begin{array}{l}\text { 几乎无 Al- } \\
\text { most no }\end{array}$ & $\begin{array}{l}\text { 八 公里 Eight } \\
\text { kilometre }\end{array}$ \\
\hline $\begin{array}{l}\text { 石栎 Lithocarpus spp. 、刺栲 Castanopsis hysir- } \\
i x \text { 、红花荷 Rhodoleia parvipetalala }\end{array}$ & 0.33 & 2080 & & $25^{\circ}$ & 黄壤 Yellow soil & 无 No & $\begin{array}{l}\text { 大围 山箐 沟 } \\
\text { Dawei Mountain } \\
\text { Qinggou }\end{array}$ \\
\hline 木果石栋 Lithocarpus xylocarpus & 0.29 & 2280 & & $20^{\circ}$ & $\begin{array}{l}\text { 黄棕壤 Yellow- } \\
\text { brown soil }\end{array}$ & $\begin{array}{l}\text { 几乎无 Al- } \\
\text { most no }\end{array}$ & $\begin{array}{l}\text { 围山顶 Top of } \\
\text { Dawei Mountain }\end{array}$ \\
\hline $\begin{array}{l}\text { 石栋 Lithocarpus spp. 杜鹃 Rhododendron } \\
\text { sp., 箭竹林 Fargesia sp. }\end{array}$ & 0.64 & 2300 & SW, NE & $35^{\circ} \sim 50^{\circ}$ & $\begin{array}{l}\text { 黄棕壤 Yellow- } \\
\text { brown soil }\end{array}$ & 极少 Few & $\begin{array}{l}\text { 大尖山顶 Top of } \\
\text { Dajian Mountain }\end{array}$ \\
\hline
\end{tabular}

$T_{\mathrm{w}} / T_{\mathrm{r}}$ ：见图 1 See Fig. 1

\section{2 植物区系聚类分析}

上述不同分布区类型的属数百分比沿垂直梯度 变化的分析结果, 表明植物区系成分构成的梯度变 化。意味着植物区系成分构成的变化特征可以被用 来探测环境梯度上植物构成的变化程度。因此, 尝 试统计用各海拔高度段上不同分布区类型所含属数 和其属下的物种种数分别与同海拔高度段上全部种 子植物属数和属下全部物种种数的百分比, 对 20 个 海拔高度段进行系统聚类, 以识别植物区系沿海拔 梯度变化的断点, 划分湿润雨林、季节性雨林带、山 地雨林带, 季风常绿阔叶林、山地苔藓常绿润叶林和 山顶苔藓矮林带的分界线。不同分布区类型属下所 含物种种数与同海拔高度段上全部物种种数的百分 比聚类, 结果见图 2a; 不同分布区类型属数与同海 拔高度段上全部属数的百分比聚类, 结果见图 $2 \mathrm{~b}$ 。

1) 在海拔段 A4 $(600 \sim 700 \mathrm{~m})$ 与 A5（700 800 $\mathrm{m}$ ）之间存在一条明显的分界线。以海拔 $700 \mathrm{~m}$ 为
界划分大围山湿润雨林与山地雨林植被带是合理 的, 其反映植物区系结构和物种组成与植被类型之 间的对应性。2) 在海拔段 A12（1400 1500 m) 与 A13 (1500 1600 m) 之间(即 $1500 \mathrm{~m}$ 附近)存在一 条明显分界线。依据吴征镒和朱彦丞 (1987)植被分 类的原则及依据进行划分所得结果也证实 $1500 \mathrm{~m}$ 附近是山地雨林分布上限。本文 3.1 节的分析也表 明在大围山海拔 $1500 \mathrm{~m}$ 是大多数热带成分分布的 上限。野外实地踏查可以观察到在大围山上山地雨 林占据一个明显的垂直带, 大致属于北热带上限海 拔 $700 \mathrm{~m}$ 至夏季云雾线 (海拔 $1000 \sim 1100 \mathrm{~m}$ ), 最高 可达海拔 $1300 \sim 1500 \mathrm{~m} 。 3$ ) 海拔 $1800 \mathrm{~m}$ (在 A15 (1 $700 \sim 1800 \mathrm{~m})$ 与 $\mathrm{A} 16(1800 \sim 1900 \mathrm{~m}$ ) 海拔段之 间)将常绿阔叶林分成不同植被亚型。事实上, 海拔 $1300 \mathrm{~m} \sim 1800 \mathrm{~m}$ 分布的是南亚热带并在季风气候 控制下形成且分布纬度最南的偏热性常绿阔叶林 季风常绿阔叶林。其组成种类主要以壳斗科的 


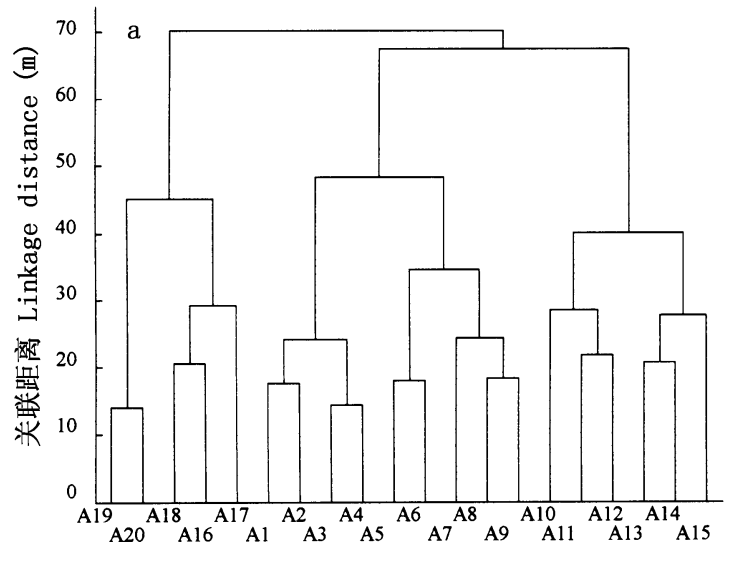

海拔带 Elevation be1t

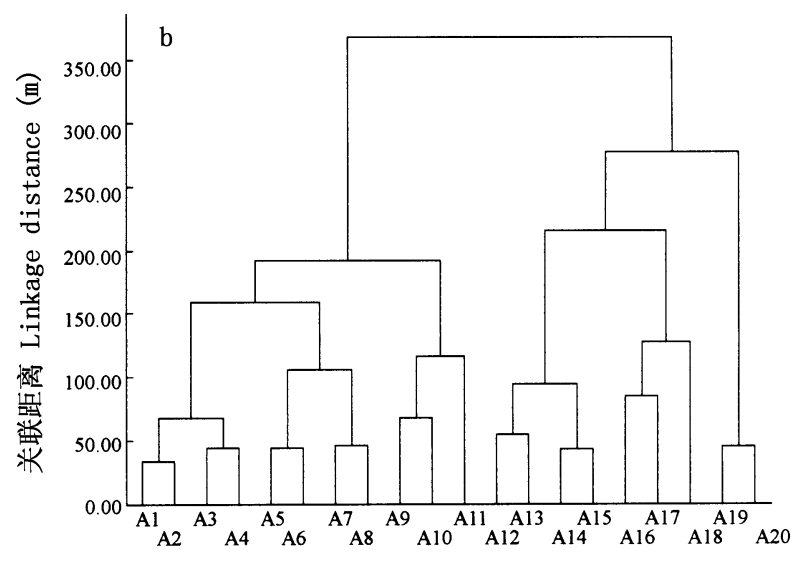

海拔带 E1evation belt

图 2 基于不同数据的大围山 20 个海拔带植物区系聚类图

Fig.2 Floristitic dendrograms of 20 elevation delts of Dawei Mountain obtained by using different data a: 基于全部属的种类构成 Based on the species composition of all genera b: 基于全部属的分布区类型构成 Based on the areal-type composition of all genera A1 A20: 从海拔 300 2300 m, 高差间隔海拔 $100 \mathrm{~m}$ 的垂直带 The vertical belts from 300-2 $300 \mathrm{~m}$ with an altitudinal interval of $100 \mathrm{~m}$

栲属( Castanopsis) 和石栎属 ( Lithocarpus)、山茶科、木 兰科、金楼梅科、冬青科、灰木科的种类为主。而 1 $800 \mathrm{~m}$ 以上则分布着热带中山山地大气湿度很大的 生境下形成的特有植被一山地苔藓常绿阔叶林。 野外调查也显示, 大围山山地苔藓常绿阔叶林分布 于海拔 $1800 \mathrm{~m} \sim 2100 \mathrm{~m}$ 之间, 气候温凉, 终年云雾 弥漫, 生境异常潮湿, 其重要特征是树干普遍附生厚 而发达的苔藓层。海拔 $2100 \mathrm{~m}$ 以上的迎风坡面, 其山脊处土层薄, 则分布有特征不甚典型的苔藓型 的山地矮林。因该区海拔高于 $2100 \mathrm{~m}$ 的山地面积 较小, 其种子植物种类有限, 且群落高度一般不高于 $10 \mathrm{~m}$, 可视为不甚典型的山顶苔藓矮林。

\section{4 结 论}

大围山植物区系整体上属于热带性质, 不存在 区系平衡点。其植物区系与越南、华南地区植物区 系的紧密联系, 与干旱生境有联系的成分所占比例 较小反映了历史上大围山地理环境的湿润状况。东 亚成分中的中国-喜马拉雅分布随海拔升高, 表现出 强烈的上升趋势, 反映了第三纪末喜马拉雅运动, 为 中国-喜马拉雅植物区系成分可沿中高山山地环境 向东南扩散创造了条件有关。

梯度分析与聚类分析较一致表明海拔 $1500 \mathrm{~m}$ 处存在一条明显的分界线, 以此为界划分大围山热 带雨林和常绿阔叶林的分界线是恰当的。大围山海 拔梯度上的植被类型及分化边界: 湿润雨林, 海拔 $700 \mathrm{~m}$ 以下; 山地雨林, 海拔 700 1500 m; 季风常绿
阔叶林, 海拔 1300 $1800 \mathrm{~m}$; 山地苔藓常绿阔叶林, 海拔 $1800 \mathrm{~m}$ 以上。聚类分析与传统的植被类型划 分方法的结果基本一致。

\section{参 考 文 献}

OCHOBbI YOA (Translated by Li XW (李锡文), Xuan SJ(宣淑 洁)) (1965). Theory of Area of Distribution (in Russian). Science Press, Beijing. (in Chinese)

Fang JY (方精云), Shen ZH (沈泽昊), Cui HT (崔海亭) (2004) . Ecological characteristics of mountains and research issues of mountain ecology. Biodiversity Science (生物多样性), 12,10 - 19. (in Chinese with English abstract)

Körner, C (2000). Why are there global gradients in species richness? Mountains might hold the answer. Tree, 15, 513- 514.

Li XW(李锡文), Li J (李捷) (1992). On the validity of tanaka line $\&$ its significance viewed from the distribution of eastern asiatic genera in Yunnan. Acta Botanica Yunnanica (云南植物研 究) , 14,1-12. (in Chinese with English abstract)

Messerli B, Ives JD(1997) . Mountains of the World: a Global Priority. The Parthenon Publishing Group, New York.

Myers N, Mittermeier RA, Mittermeier CG (2000). Biodiversity hotspots for conservation priorities. Nature, 403, 853-857.

Rohde K (1992). Latitudinal gradients in species diverisity: the search for the primary cause. Oikos, 65, 514-527.

Rosenzweig ML(1992). Species diverisity gradients: we know more and less than we thought. Journal of Mammalogy, 73, 715 730 .

Rosenzweig ML(1995). Species Diverisity in Space and Time. University of Chicago Press, Chicago, $1-73$.

Shen ZH(沈泽吴), Zhang XS (张新时), Jin YX (金义兴) (2001). A vertical gradient analysis of the flora of Dalaoling 
Mountain in the Three Gorges region, China. Acta Phytotaxonomica Sinica (植物分类学报), 39, 260-268. (in Chinese with English abstract)

Shui YM(税玉民) (2003). The Seed Plants of the Honghe Region in Southeast Yunnan (滇东南红河地区种子植物). Yunan Science and Technology Publishing House, Kunming. (in Chinese with English abstract)

Tang SZ (唐守正) (1986). The Methods of Multivariate Statistical Analysis (多元统计分析方法). China Forestry Publishing House, Beijing. (in Chinese)

Wu ZY (吴征镒), Zhu YC (朱彦丞) (1987). Vegetation of Yunnan (云南植被). Science Press, Beijing. (in Chinese)

Wu ZY (吴征镒) (1991). The areal-types of Chinese genera of seed plants. Acta Botanica Yunnanica (云南植物研究), Suppl. IV , 1 - 139. (in Chinese with English abstract)

Wu ZY (吴征镒) (1980). Vegetation of China (中国植被). Science Press, Beijing. (in Chinese)

Xu KX(徐克学) (1994). Quantitative Taxonomy (数量分类学). Science Press, Beijing. (in Chinese)

Yang HX(阳含熙), Lu ZY (卢泽愚) (1981). Quantative Taxonomy in Plant Ecology (植物生态学的数量分类方法). Science Press, Beijing. (in Chinese)

Zhou TR(周庭儒), Ren SH(任森厚) (1984). China's Physical Geography-Paleogeography (中国自然地理・古地理). Science Press, Beijing. (in Chinese)

责任编委: 董 鸣 责任编辑: 姜联合, 李 敏 